\title{
Twenty-year assessment of Lignum-vitae (Guaiacum sanctum, Zygophyllaceae) in the Palo Verde National Park of Costa Rica
}

Ulises Balza ${ }^{1} \&$ Roland C. de Gouvenain*2

1. Laboratorio de Ecología y Conservación de Vida Silvestre. Centro Austral de Investigaciones Científicas (CADICCONICET) Bernardo Houssay 200, Ushuaia, Argentina; ulisesbalza@cadic-conicet.gob.ar, ulisesbalza@gmail.com

2. Rhode Island College; Department of Biology; 600 Mount Pleasant Avenue, Providence, RI 02908; rdegouvenain@ric.edu * Correspondence

Received 14-VII-2019. Corrected 12-IX-2019. Accepted 20-IX-2019.

\begin{abstract}
Introduction: The Lignum-vitae (Guaiacum sanctum; Zygophyllaceae), of Mesoamerica and the Greater Antilles, is threatened over much of its range. We evaluated whether a G. sanctum population in the Palo Verde National Park of Costa Rica is viable in the long term. Methods: Using two demographic studies, one in 1997 and the other in 2017, we estimated survival and fecundity rates for each tree age class, population growth rate $(l a m b d a)$, and vital rates elasticity, and we used a density-independent deterministic population model to project the long-term trend of that population. Results: The estimated vital rates during the last 20 years suggested that this population is rapidly decreasing. Although some age classes increased in abundance, seedlings are rare and the plants that recruited in 1997 have not yet reached reproductive maturity. Our results suggest that the current abundance of $G$. sanctum within the national park may not be a good indicator of its long-term conservation status, and from our population viability analysis, we estimated that the population we studied would decrease to less than $1 \%$ of its current size within the next 200 years. Conclusions: Landscape-scale ecosystem deterioration affecting the greater PVNP region, such as loss of seed dispersers and suppression of disturbances, may offset the passive protection of $G$. sanctum within park boundaries. Relying on the overall strict protection afforded by the location of the population within the Palo Verde National Park may not be sufficient to conserve this population of G. sanctum. We recommend that more proactive experimental protection and/or restoration measures, possibly including disturbance treatments, be implemented within a research program.
\end{abstract}

Key words: demography, disturbance, conservation, Guayacán, park management, PVA, tropical dry forest.

Balza, U., \& de Gouvenain, R. C. (2019). Twenty-year assessment of Lignum-vitae (Guaiacum sanctum, Zygophyllaceae) in the Palo Verde National Park of Costa Rica. Revista de Biología Tropical, 67(6), 1269-1277.

Although national parks have been shown to protect natural resources from land clearing, logging, and hunting in the tropics (Bruner et al., 2001), and even to promote reforestation when compared to similar unprotected areas (Andam et al., 2013), fragmentation of the tropical forest surrounding a national park can lead to the local extirpation of a rare, threatened, and/or endangered tree species, even if its habitat is protected and retains its original structure within the park itself. This is because key ecosystem processes, especially the free movement of animal pollinators and seed dispersers that are critical to some tree species, may be lost. For instance, small and isolated reserves in the Atlantic forest of Northeast Brazil are losing 
large-seeded zoochorous trees (often the rarest and most threatened species) in favor of smallseeded trees because the birds and vertebrate dispersers of large seeds have been extirpated by habitat fragmentation and hunting (da Silva \& Tabarelli, 2000). Restoring natural forested landscapes in protected areas may thus not be sufficient to ensure the conservation of all the ecological processes that support endangered tree species if the movement of animals across the greater landscape surrounding those protected areas is not reestablished as well (Kushlan, 1979). Yet, this issue is rarely assessed in reserves and national parks worldwide.

The Lignum-vitae or Guayacán Real (Guaiacum sanctum L., family Zygophyllaceae) is a relatively small $(25-30 \mathrm{~m})$, slowgrowing tree species that can live for more than 500 years, and that was originally found from sea level to $200 \mathrm{~m}$ elevation in dry tropical forests from Mexico to Venezuela, including on islands such as Cuba, Puerto Rico, and Hispaniola (Jiménez-Madrigal, 1999; LópezToledo et al., 2011; López-Toledo et al., 2012), and on one island (Lignumvitae Key) of the Florida Keys, USA (Dertien \& Duvall, 2009). Formerly much more abundant and continuous, the dry forests of Mesoamerica have been logged and converted to pastures for 400 years, and many populations of precious wood species like G. sanctum have been extirpated. For instance, over $75 \%$ of tropical dry forest has been converted to other land uses in Costa Rica (Portillo-Quintero \& SanchezAzofeifa, 2010). The Lignum-vitae was heavily exploited throughout its range in the 1960s for the quality of its wood, and it is today classified as Near Threatened (IUCN, 2019), with patches distributed mostly in Southern Mexico, Guatemala, Honduras, Lignumvitae Key, and in Costa Rica, where only six small populations currently exist, only three of which are within protected areas (Jiménez-Madrigal, 1999; López-Toledo et al., 2008), and where Lignum-vitae is included in Appendix II of CITES (Jiménez-Madrigal et al., 2016). In Mexico, the smallest reproductive trees are 1-5 $\mathrm{cm}$ in diameter, which corresponds to an age of
30 to 70 years, and produce approximately 10 fruits, while large ( $>35 \mathrm{~cm}$ diameter) reproductive adults can produce more than 10000 fruits (López-Toledo et al., 2008). In Cuba, populations of $G$. sanctum ( $>2500$ adult trees) are reported to be stable (CITES, 2000) but the species is currently listed as Data Deficient (González Torres et al., 2016). Costa Rican populations of G. sanctum in the Palo Verde National Park (PVNP), established to conserve one of the last dry forests in Costa Rica, an endangered ecosystem in the Neotropics (Jiménez-Madrigal et al., 2016), have been protected since 1978, and the cutting of the Lignum-vitae has been prohibited nationwide since 1997. Despite forest fragmentation and extractive harvesting, G. sanctum populations in Costa Rica appear to have enough genetic potential to recover (Fuchs \& Hamrick, 2010, a, b).

We asked whether a population of $G$. sanctum protected within the PVNP was demographically stable, declining, or increasing, as it should be given its protection from harvesting for the last 40 years. Our hypothesis was that the protection against tree harvesting in the PVNP had been sufficient to ensure the long-term viability of populations of $G$. sanctum. Given our assumption that individuals that were seedlings 20 years ago would have, if they survived, recruited into the juvenile and/or subadult age classes as of 2017, our predictions were that (1) regeneration would be widespread in 2017, and (2) the population would be stable or increasing, and thus viable in the long term. In 1997, 20 years after the establishment of the PVNP, we concluded that the G. sanctum population we focus on in this study was recovering due to the abundance of seedlings, despite the presence of very few adult trees. We then reexamined that same population of $G$. sanctum 20 years later to estimate its long-term viability. We used population viability analysis (hereafter PVA, Morris et al., 1999), which utilizes the available demographic information to estimate projected populations deterministically or stochastically (Lindenmayer et al., 1993; Akçakaya, 2000; Maschinski et al., 2006). Despite its limitations, PVA is a tool that is increasingly 
used for trees because of the long timescales at which demographic processes take place with those organisms (Menges, 1990, 2000).

\section{MATERIALS AND METHODS}

Study site: The PVNP is located in the Tempisque River Basin, the largest basin in Costa Rica (Jiménez \& González Jiménez, 2001). Predominant soils in the park are inceptisols, with mixed textures and intermediate development (Mateo-Vega, 2001), but most of the Guaiacum populations occur in the moister limestone hills of the Cerro Guayacán, with undulating topography and greater species diversity than in the rest of the park (JiménezMadrigal et al., 2016). Annual average temperature in PVNP is $25{ }^{\circ} \mathrm{C}$ and precipitation is seasonal, with approximately $1300-1700$ $\mathrm{mm}$ falling during the May-to-December rainy season (Gillespie et al., 2000). The park contains large areas of limestone hills covered by a dense seasonally dry forest. The most common tree species include Bursera simaruba (L.) Sarg., Pachira quinata W.S. Alverson (= Bombacopsis quinata Dugand), and Astronium graveolens Jacq. (Janzen, 1983). We conducted the two demographic surveys in the same 0.8 ha study area, located $500 \mathrm{~m}$ north of the PVNP Biological Station $\left(10^{\circ} 20^{\prime} 58^{\prime \prime}\right.$ N \& $\left.85^{\circ} 21^{\prime} 01^{\prime \prime} \mathrm{W}\right)$ at $50 \mathrm{~m}$ elevation, in 1997 and 2017, with a few minor differences between the two surveys (Fig. 1). Within $5 \mathrm{~m}$ on either side of the "Guayacán" (Spanish common name of $G$. sanctum) trail and for approximately $200 \mathrm{~m}$ along the trail, we measured the basal diameter or the diameter at breast height (DBH, depending on the tree size), with calipers or a DBH tape, respectively, of all 4-cm or taller G. sanctum individuals, and classified them in 5 diameter stages modified from five height classes used by Fuchs et al. (2013). We assumed that only stage 5 (diameter $>100 \mathrm{~mm}$ ) contained reproductive individuals, based on the observation of López-Toledo et al. (2008) that smaller diameter trees produced seeds,

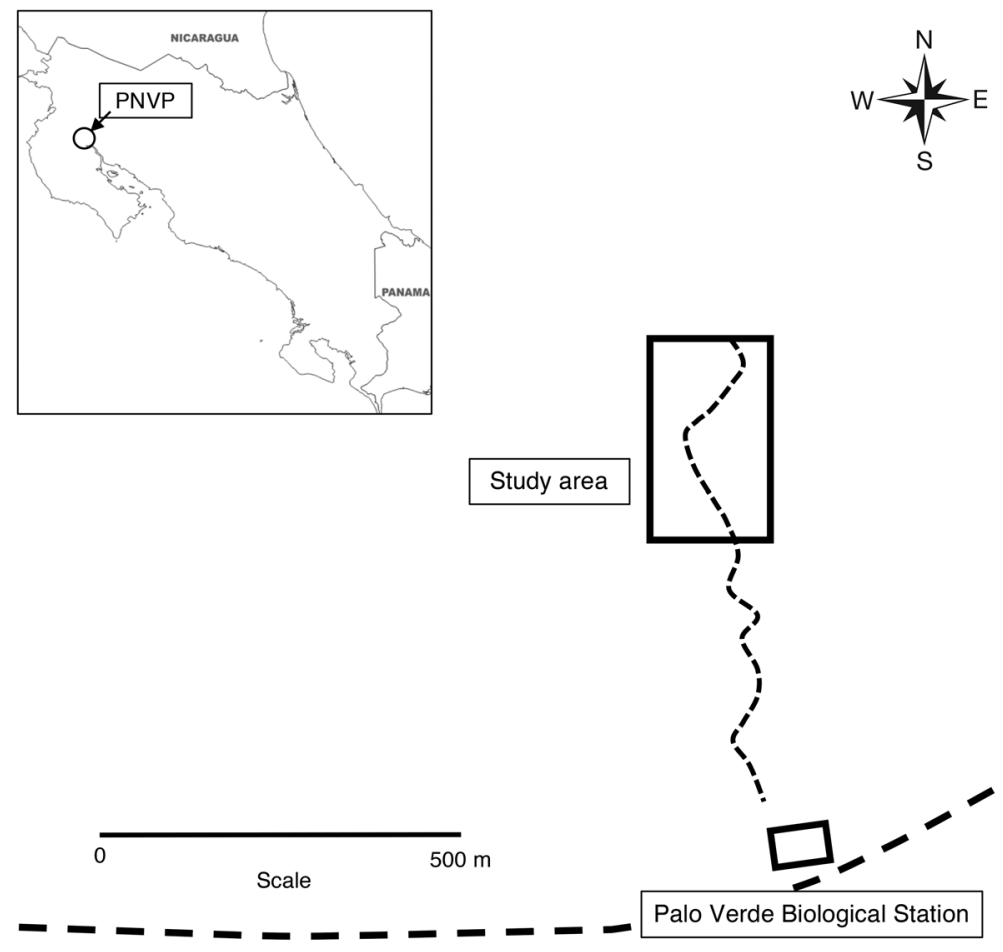

Fig. 1. Study area. Inset: location of the PVNP in Costa Rica. 
but in very small quantities compared to trees with diameter $>100 \mathrm{~mm}$ (Fig. 2a). In 1997, we recorded the diameter/DBH of a total of $286 \mathrm{G}$. sanctum individuals within the study area (all stems $50 \mathrm{~cm}$ tall or taller, and a subsample of individuals $<50 \mathrm{~cm}$ tall, for which data were then extrapolated to the entire study area). In 2017, we recorded the diameter/DBH of all 427 G. sanctum individuals within the same study area, including all stems $<50 \mathrm{~cm}$ tall.

Data analysis and PVA: We carried out a deterministic (i.e., assuming no variation of vital rates) PVA using a density independent growth model (Akçakaya et al., 1999) that assumed a closed population (no gene flow with any other population), constant vital rates for each age class, and unlimited resources available to the population (Gotelli, 2001). Our closed population assumption is realistic since the nearest population of G. sanctum is $10 \mathrm{~km}$ away, in Cerro Rosario (Jiménez-Madrigal, 1999 ) and G. sanctum pollen travels only up to $4 \mathrm{~km}$ (Fuchs \& Hamrick, 2010a). We used $\mathrm{N}(t+1) / \mathrm{N}(t)$ as an estimate of the survival rates of each stage $t$, assuming that 1997-recorded individual plants either grew to the next stage $(t+1)$ or died during the 20-year span of the study. We also assumed that stage 5 was the only stage within which individuals could have remained during the 1997-2017 period. To estimate if the 2017 census individuals in stage 5 grew from stage 4 or stayed within stage 5 since 1997, we compared the DBH of stage 5 individuals between the two periods. Out of three individuals that were in stage 5 in 1997 , we found only one live and one dead in 2017 (and one of the three trees was missing), so we assumed a 0.33 survival probability for stage 5 individuals; all other individuals we found in stage 5 in 2017 had to have recruited into that stage from individuals that were in stage 4 in 1997. Our PVA was based on the iteration of a Lefkovitch transition matrix (Gotelli, 2001) that contained vital rates estimated from a matrix of initial 2017 abundances of individuals of each stage (Fig. 2b). We also calculated the intrinsic population growth rate lambda, and an elasticity matrix to estimate which vital rate(s) have a larger effect on lambda (Turchin, 2003). All iterations and calculations were made in R (R Core Team 2013) based on Gotelli's (2001) equations.

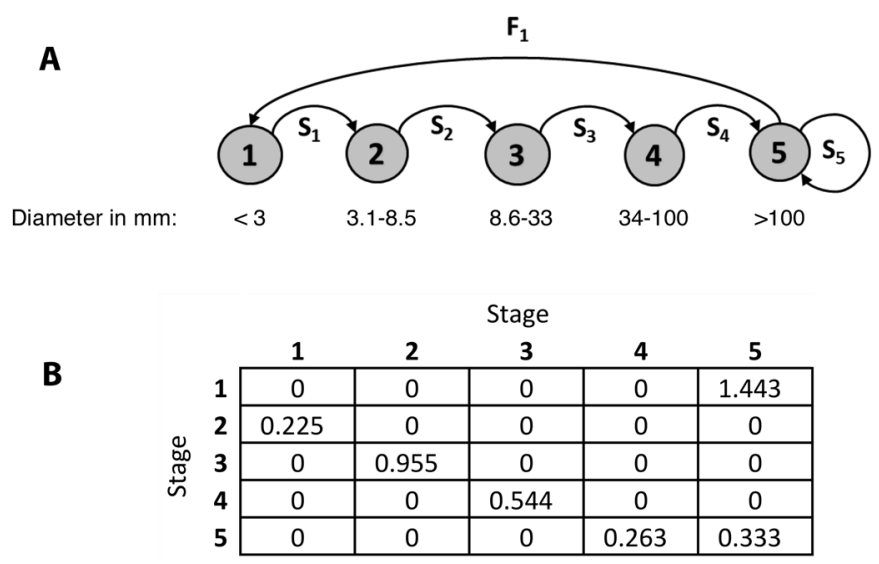

Fig. 2. A. Life cycle graph for Guaiacum sanctum, modified from Fuchs et al. (2013). Gray nodes represent life stages, while arrows indicate the transitions from one diameter stage to another per probability $\mathrm{S}_{i}$, and the fertility of stage 5 per $\mathrm{F}_{1}$, the number of individuals contributed to stage 1 weighted by $\mathrm{S}_{5}$, the survival of the reproductive stage 5. Stages: $1=$ seedlings, 2 = saplings, 3 = juveniles, 4 = sub-adults, 5 = adults. B. Lefkovitch matrix used to carry out the population viability analysis. Cell values represent $\mathrm{F}_{1}$, the recruitment into stage 1 (row 1), and transition probabilities $\mathrm{S}_{1}, \mathrm{~S}_{2}, \mathrm{~S}_{3}, \mathrm{~S}_{4}$ and $\mathrm{S}_{5}$ (rows 2 through 5, respectively). 


\section{RESULTS}

In 1997, we estimated the number of seedlings to be 1300 seedlings ha ${ }^{-1}$ from our subsample of individuals $<50 \mathrm{~cm}$ tall. In 2017 , most of the individuals we inventoried were in intermediate stages, with a fair number of stage- 5 reproductive adults $\left(15\right.$ stems ha $\left.^{-1}\right)$, but we found very few seedlings ( 65 stems ha $^{-1}$ ), and a population that had overall diminished by $35 \%$ since 1997, which is equivalent to a $1.75 \%$ annual decrease assuming a linear relation. In 1997, adult individuals (5-10 stems $\mathrm{ha}^{-1}$ ) were all near the upper age limit of stage 5 , whereas in 2017, many of the individuals in the terminal stage 5 were close to the lower diameter limit for that stage. The difference in frequencies between the two inventories was due to an increase in abundance of individuals within stages 3 and 4 , and a decrease within stages 1 and 2. Numbers of individuals within stage 5 were similar for both periods (Fig. $3)$. The population growth rate lambda, estimated from the Lefkovitch transition matrix, was 0.62 , which indicates that the population has been decreasing, and the PVA projected a population decrease of more than $99 \%$ within the next 200 years (Fig. 4). A hypothetical PVA model carried out with a stage 5 survival rate
$\mathrm{S}_{5}=0.885$ for comparison (figure not shown) would allow that same population to reach lambda $>1$ and to be sustainable in the long term. Elasticity analysis (figure not shown) suggested that both, survivorship of all stages and fecundity of stage 5 , were vital rates with approximately equal influence on lambda.

\section{DISCUSSION}

Our study suggests that the G. sanctum population north of the PVNP Biological Station may not be viable in the long term, and our viability analysis projection suggests a probable extirpation within the next 200 years, possibly because of the low rate of recruitment into the first seedling stage. Deterministic, densityindependent PVA models are commonly used in plant population ecology (Menges, 2000), but they also represent an oversimplification of natural population dynamics. In fact, our projection for the PVNP Biological Station population is mathematically an overestimation of the extinction time, since every complexity added to a projection model (such as stochasticity) adds more uncertainty and provides shorter estimated extinction times (Morris et al., 1999). In agreement with findings by Fuchs et al. (2013), although there were new stage 5

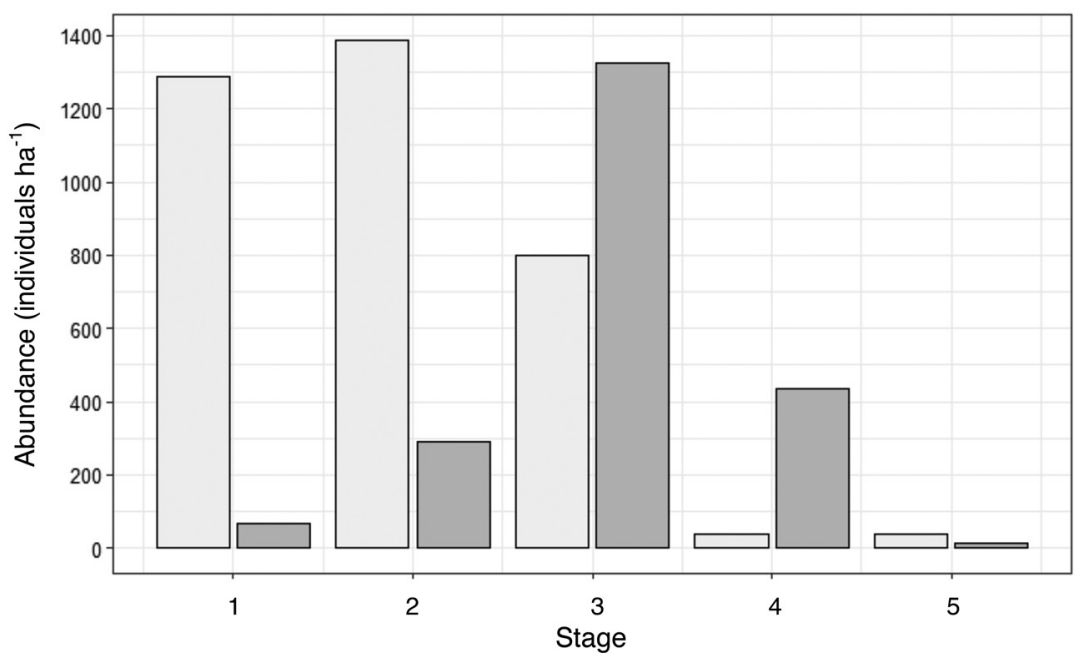

Fig. 3. Abundance of G. sanctum individuals per ha in each diameter size class in 1997 (light gray) and 2017 (dark gray). 


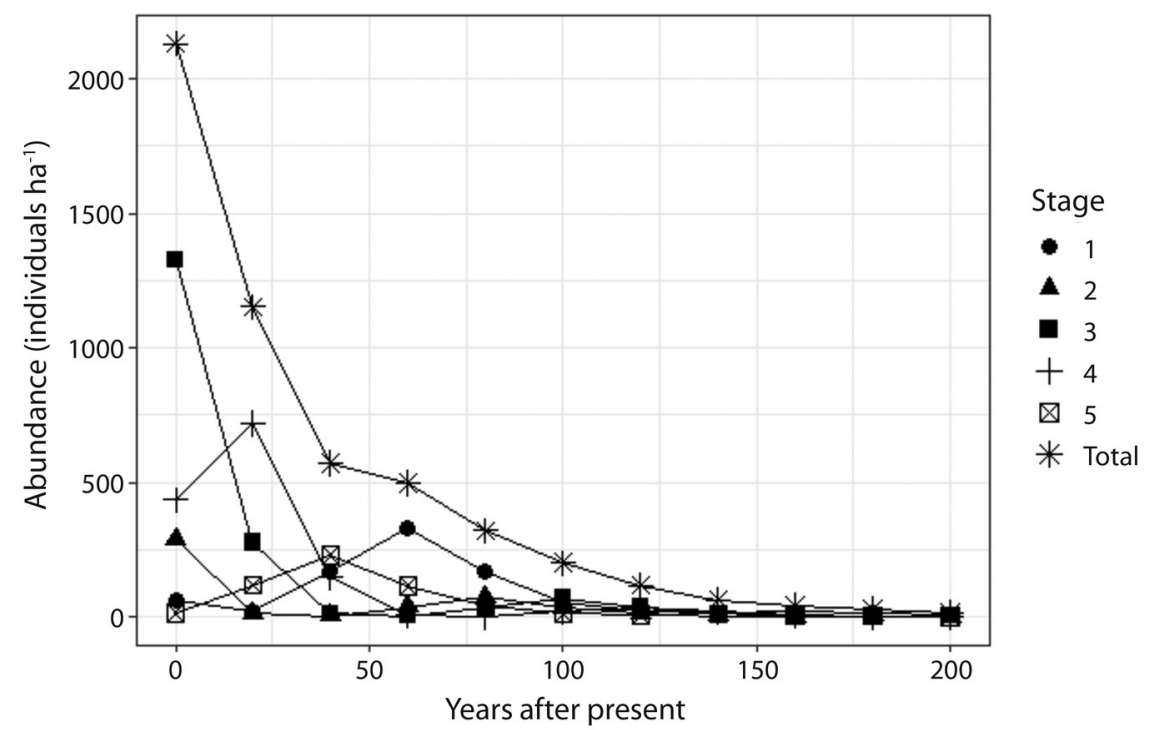

Fig. 4. Abundance of $G$. sanctum individuals per ha projected over the next 200 years for each stage.

reproductive adults in the population in 2017, a large gap of diameters was found in that stage, suggesting that fecundity rate may not be well described by the mean used in the population projections. In 1997, seedlings were abundant, just as they were in 2003-2004 when Fuchs et al. (2013) recorded seedlings amounting to $65 \%$ of all individuals in the same $G$. sanctum population. The low 2017 seedling count could indicate that unfavorable conditions for the establishment of seedlings are a recent phenomenon. Other studies reported different results from ours with respect to the regeneration of Lignum-vitae in the PVNP and its environs. Jiménez-Madrigal et al. (2016) observed evidence of natural regeneration of G. sanctum in the Tempisque River Basin, and Acosta et al. (2017) found $63 \%$ of individuals in the seedling stage for populations in Honduras. Senescence and diminishing fertility of the oldest trees, combined with the fact that the new reproductive adults recently recruited into stage 5 may not yet be in their reproductive peak, could explain the low seedling counts we observed in 2017. In the Cuajiniquil (Northwestern Costa Rica) population of G. sanctum, Fuchs and Hamrick (2011) observed between 17 and $63 \%$ of the adults flowering each year, and only three adults generating $40 \%$ of the seedlings.

Although we did not examine the possible effect of exogenous regional processes on the recent dynamics of this PVNP population of $G$. sanctum, many studies have highlighted the often-unrecognized regional dynamics that can influence plant populations that are theoretically protected within park boundaries. In many protected Neotropical forest fragments, populations of some large herbivores have increased because of hunting restrictions and diminished numbers of natural predators (Peres, 1996). For instance, there has not been any sighting of a jaguar in the PVNP since 2000 (Farji-Brener, pers. comm.). Lack of seed dispersers, especially birds, could also result in poor seedling recruitment, since the fruits of G. sanctum are eaten, and their seeds dispersed away from parent trees, by several bird species (Wendelken \& Martin, 1987), and seed scarification through the digestive tract of granivorous birds is known to increase germination rates of G. sanctum seeds (SánchezSoto et al., 2017). Lack of suitable habitat connectivity between the PVNP and other protected areas of Costa Rica could result in low seed-dispersing avian populations within the 
PVNP (Sánchez-Azofeifa et al., 2003). Finally, several populations of $G$. sanctum are globally found in areas regularly affected by natural or human disturbances. For instance, the Lignumvitae Key population is regularly disturbed by hurricanes that promote increased light levels in the forest understory and may thus benefit seed germination and seedling survival (Dertien \& Duvall, 2009), and in Northern Yucatan, Mexico, a study comparing recently logged and protected G. sanctum stands paradoxically registered the highest Lignum-vitae seedling densities in the logged areas, and the lowest densities within protected areas (López-Toledo et al., 2011). In Nicaragua, low intensity surface prescribed burning of G. sanctum stands that had not burned in over 20 years increased Lignum-vitae seedling densities compared to those in unburned plots one year after the experiment, and adult $G$. sanctum trees were not negatively affected by the prescribed burning, suggesting a possible adaptation to fire (Otterstrom et al., 2006).

Given the low 2017 recruitment of $G$. sanctum seedlings, and to better understand the population dynamics of this species, we recommend that the current PVNP management of this endangered species be adapted to promote an on-the-ground research agenda that could include: (1) studying the phenology of $G$. sanctum to better understand its regeneration requirements; (2) conducting comparative release harvesting treatments of overstory trees of species other than G. sanctum in Lignum-vitae stands to investigate the effects of increased understory light levels on seedling recruitment and survival, and on adult tree fecundity; (3) conducting small-scale lowintensity prescribed burning experiments following major seed release by adult $G$. sanctum trees to increase scarification of seedbeds and to compare recruitment with that in unburned stands; (4) installing camera traps within $G$. sanctum stands to investigate levels of seedling herbivory and the animal species that may be responsible for that herbivory; (5) monitoring G. sanctum populations across the Guanacaste region to distinguish between local episodic high recruitment and true regional metapopulation growth (Kwit et al., 2004); (6) initiating a global assessment of the Lignum-vitae to clarify its conservation status and to design conservation and restoration strategies that ensure its long-term conservation, in collaboration with other regional conservation actors in the Guanacaste Province. Our results also suggest that the down-listing of this species to Near Threatened (IUCN, 2019) may not be justified, since we found evidence of a $37 \%$ decline in 20 years, enough to warrant listing of that species as Vulnerable under IUCN criterion A.

In conclusion, although the Costa Rican national parks system has been a model for biodiversity conservation globally (Boza, 1993), our study suggests that the conservation of $G$. sanctum may not be guaranteed within the limits of the PVNP, even though its harvesting is no longer permitted. We recommend that comparative research experiments be carried out among the PVNP Lignum-vitae populations to better understand if the current population decline our study documented is due to local (endogenous) or regional (exogenous) processes, and to ensure the long-term conservation of this species.

\section{ACKNOWLEDGMENTS}

This study was carried out during two Organization for Tropical Studies (OTS) Tropical Ecology and Conservation courses in Costa Rica, with Deedrea McClearn, Theresa Singer, and Victor Carmona (1997), and Federico Chinchilla, Fernando Soley and Karla ConejoBarboza (2017), as coordinators. Christopher Paciorek and Amy Kaplan helped with field work and provided valuable suggestions for the 1997 study. We also thank Diana RodríguezCala and Ernesto Testé for generously sharing their knowledge of the general biology and the conservation status of $G$. sanctum, and to Mahmood Sasa and Ulises Chavarría, of the PVNP, for their support. We are grateful to three anonymous reviewers for their constructive and helpful comments. 


\section{RESUMEN}

Evaluación de veinte años de Lignum-vitae (Guaiacum sanctum, Zygophyllaceae) en el Parque Nacional Palo Verde de Costa Rica. Introducción: El guayacán real (Guaiacum sanctum; Zygophyllaceae) de Mesoamérica y las Antillas está amenazado en gran parte de su área de distribución. Evaluamos si una población de G. sanctum en el Parque Nacional Palo Verde en Costa Rica es viable a largo plazo. Métodos. Usando dos estudios demográficos, uno en 1997 y otro en 2017, estimamos las tasas de supervivencia y fecundidad para cada clase de edad, la tasa de crecimiento poblacional (lambda), y las elasticidades para cada tasa vital, y usamos un modelo determinístico densoindependiente para proyectar la trayectoria a largo plazo de la población. Resultados: las tasas vitales estimadas durante los últimos 20 años sugieren que esta población está disminuyendo rápidamente, con un lambda estimado de 0.62 . Aunque algunas clases de edad aumentaron en abundancias, los renovales son raros y los individuos reclutados en 1997 aún no alcanzaron la madurez reproductiva. Nuestros resultados sugieren que la abundancia actual de G. sanctum dentro del Parque Nacional podría no ser un buen indicador del estado de conservación a largo plazo, y por nuestro análisis de viabilidad poblacional, estimamos que la población estudiada disminuiría a menos del $1 \%$ de su actual abundancia en los próximos 200 años. Conclusiones: el deterioro ecosistémico a escala de paisaje esta afectando la región del Parque Nacional Palo Verde, como la pérdida de dispersores de semillas y la supresión de alteraciones, podría compensar la protección pasiva de G. sanctum dentro de los límites del Parque Nacional. Confiar en la estricta protección dada por la locación de la población dentro del parque podría no ser suficiente para conservar esta población de G. sanctum. Recomendamos incorporar, dentro de un programa de investigación, una protección experimental más proactiva y/o medidas de restauración, posiblemente incluyendo tratamientos de alteraciones.

Palabras clave: demografía, alteración, conservación, Guayacán, manejo de áreas protegidas, AVP, bosque tropical seco.

\section{REFERENCES}

Acosta, L. F., Ordoñez, T. M., \& Andino, R. C. (2017). Estudio poblacional de Guaiacum sanctum L. (Zygophyllaceae) en los bosques secos de Honduras. Revista Ciencia y Tecnología, 19, 78-93.

Akçakaya, H. R. (2000). Population viability analyses with demographically and spatially structured models. Ecological Bulletins, 48, 23-38.

Akçakaya, H. R., Burgman, M. A., \& Ginzburg, L. R. (1999). Applied Population Ecology: Principles and Computer Exercises Using RAMAS® EcoLab (2 $2^{\text {nd }}$ ed.). Sunderland, MA: Sinauer.
Andam, K. S., Ferraro, P. J., \& Hanauer, M. M. (2013). The effects of protected area systems on ecosystem restoration: a quasi-experimental design to estimate the impact of Costa Rica's protected area system on forest regrowth. Conservation Letters, 6(5), 317-323.

Boza, M. A. (1993). Conservation in action: Past, present, and future of the national park system of Costa Rica. Conservation Biology, 7, 239-247.

Bruner, A. G., Gullison, R. E., Rice, R. E., \& da Fonseca, G. A. B. (2001). Effectiveness of parks in protecting tropical biodiversity. Science, 291, 125-128.

CITES, (2000). Proposal: Transfer of Guaiacum sanctum from Appendix II to Appendix I. Convention on International Trade in Endangered Species of Wild Fauna and Flora (CITES), Nairobi, Kenya.

da Silva, J. M. C., \& Tabarelli, M. (2000). Tree species impoverishment and the future flora of the Atlantic forest of northeast Brazil. Nature, 404, 72-74.

Dertien, J. R., \& Duvall, M. R. (2009). Biogeography and divergence in Guaiacum sanctum (Zygophyllaceae) revealed in chloroplast DNA: Implications for conservation in the Florida Keys. Biotropica, 41, 120-127.

Fuchs, E. J., \& Hamrick, J. L. (2010a). Genetic diversity in the endangered tropical tree, Guaiacum sanctum (Zygophyllaceae). Journal of Heredity, 101, 284-291.

Fuchs, E. J., \& Hamrick, J. L. (2010b). Spatial genetic structure within size classes of the endangered tropical tree Guaiacum sanctum (Zygophyllaceae). American Journal of Botany, 97, 1200-1207.

Fuchs, E. J., \& Hamrick, J. L. (2011). Mating system and pollen flow between remnant populations of the endangered tropical tree, Guaiacum sanctum (Zygophyllaceae). Conservation Genetics, 12, 175-185.

Fuchs, E. J., Robles, T., \& Hamrick, J. L. (2013). Spatial distribution of Guaiacum sanctum (Zygophyllaceae) seedlings and saplings relative to canopy cover in Palo Verde National Park, Costa Rica. Revista de Biología Tropical, 61, 1521-1533.

Gillespie, T. W., Grijalva, A. \& Farris, C. N. (2000). Diversity, composition, and structure of tropical dry forests in Central America. Plant Ecology, 147(1), 37-47.

González Torres, L. R., Palmarola, A., González Oliva, L., Bécquer, E. R., Testé, E., \& Barrios, D. (2016). Lista roja de la flora de Cuba. Bissea, 10(número especial $1), 1-352$.

Gotelli, N. J. (2001). A Primer of Ecology (3 ${ }^{\text {rd }}$ ed.). Sunderland, MA: Sinauer.

IUCN. (2019). The IUCN Red List of Threatened Species. Version 2015.1. Gland, Switzerland: International Union for Conservation of Nature. 
Janzen, D. H. (1983). Costa Rican Natural History. Chicago, IL: University of Chicago Press.

Jiménez, J. A. \& González Jiménez, E. (2001). La Cuenca del Río Tempisque: perspectivas para un manejo integrado. San José, CR: Organización para Estudios Tropicales.

Jiménez-Madrigal, Q. (1999). Consideraciones sobre el manejo y conservación de 18 especies forestales vedadas en Costa Rica. Guaiacum sanctum L. (guayacán real), un caso particular de estudio. Sevilla, Spain: Universidad Internacional de Andalucía.

Jiménez-Madrigal, Q., Carrillo, E. J., \& Kapelle, M. (2016). The Northern Pacific Lowland Seasonal Dry Forest of Guanacaste and the Nicoya Peninsula. In M. Kapelle (Ed.), Costa Rican Ecosystems (pp. 247289). Chicago, IL: The University of Chicago Press.

Kushlan, J. A. (1979). Design and management of continental wildlife reserves: Lessons from the everglades. Biological Conservation, 15, 281-290.

Kwit, C., Horvitz, C. C., \& Platt, W. J. (2004). Conserving slow-growing, long-lived tree species: Input from the demography of a rare understory conifer, Taxus floridana. Conservation Biology, 18, 432-443.

Lindenmayer, D. B., Clark, T. W., Lacy, R. C., \& Thomas, V. C. (1993). Population viability analysis as a tool in wildlife conservation policy: with reference to Australia. Environmental Management, 17(6), 745-758.

López-Toledo, L., Burslem, D. F. R. P., Martínez-Ramos, M., \& García-Naranjo, A. (2008). Non-detriment findings report on Guaiacum sanctum in Mexico. Workshop Case Study WG1-Trees No. 7 (WG1-CS7). Cancun, Mexico: NDF International Expert Workshop on CITES Non-Detriment Findings.

López-Toledo, L., Murillo-García, A. Martínez-Ramos, M. \& Pérez-Salicrup, D. R. (2011). Demographic effects of legal timber harvesting on Guaiacum sanctum L., an endangered neotropical tree: implications for conservation. Interciencia, 36(9), 650-656.

López-Toledo, L., Ibarra-Manríquez, G., Burslem, D. F. R. P., Martínez-Salas, E., Pineda-García, F., \& MartínezRamos, M. (2012). Protecting a single endangered species and meeting multiple conservation goals: An approach with Guaiacum sanctum in Yucatan Peninsula, Mexico. Diversity and Distributions, 18, 575-587.

Maschinski, J., Baggs, J. E., Quintana-Ascencio, P. F., \& Menges, E. S. (2006). Using population viability analysis to predict the effects of climate change on the extinction risk of an endangered limestone endemic shrub, Arizona Cliffrose. Conservation Bio$\log y, 20,218-228$.

Mateo-Vega, J. (2001) Características generales de la cuenca del Río Tempisque. In R. J. A. Jiménez \& J. E. González (Eds.), La Cuenca del Río Tempisque: perspectivas para un manejo integrado (pp. 32-72). San José, CR: Organización para Estudios Tropicales.

Menges, E. S. (1990). Population viability analysis for an endangered plant. Conservation Biology, 4(1), 52-62.

Menges, E. S. (2000). Population viability analyses in plants: challenges and opportunities. Trends in Ecology \& Evolution, 15, 51-56.

Morris, W., Doak, D., Groom, M., Kareiva, P., Fieberg, J., Gerber, L., Murphy, P., \& Thomson, D. (1999). A Practical Handbook for Population Viability Analysis. The Nature Conservancy.

Otterstrom, S. M., Schwartz, M. W., \& Velázquez-Rocha, I. (2006). Responses to fire in selected tropical dry forest trees. Biotropica, 38(5), 592-598.

Peres, C. A. (1996). Population status of white-lipped Tayassu pecari and collared peccaries T. tajacu in hunted and unhunted Amazonian forests. Biological Conservation, 77, 115-123.

Portillo-Quintero, C. A. \& Sánchez-Azofeifa, G. A. (2010). Extent and conservation of tropical dry forests in the Americas. Biological Conservation, 143, 144-155.

R Core Team (2013) R: A language and environment for statistical computing. Vienna, Austria: R Foundation for Statistical Computing.

Sánchez-Azofeifa, G. A., Daily, G. C., Pfaff, A. S. P., \& Busch, C. (2003). Integrity and isolation of Costa Rica's national parks and biological reserves: examining the dynamics of land-cover change. Biological Conservation, 109, 123-135.

Sánchez-Soto, B. H., Pacheco-Aispuro, E., Lugo-García, G. A., Reyes-Olivas, Á., \& García-Moya, E. (2017). Métodos de escarificación en semillas de Guaiacum coulteri, especie amenazada del bosque tropical caducifolio del norte de Sinaloa, México. Gayana Botánica, 74(2), 262-268.

Turchin, P. (2003). Complex Population Dynamics: A Theoretical/Empirical Synthesis. Princeton, NJ: Princeton University Press.

Wendelken, P. W. \& Martin, R. F. (1987). Avian Consumption of Guaiacum sanctum fruit in the arid interior of Guatemala. Biotropica, 19(2), 116-121. 